\title{
Aktivitas Promosi Badan Promosi Pariwisata Daerah Kabupaten Ciamis melalui Kegiatan Desaku Wisataku
}

\author{
Dhaifina Fakhrana*, Zulfebriges \\ Prodi Manajemen Komunikasi, Fakultas Ilmu Komunikasi, Universitas Islam \\ Bandung, Indonesia. \\ *dhaifinafakhrana@gmail.com, zulfebriges@gmail.com
}

\begin{abstract}
The activity of the Desaku Wisataku is an annual routine program of the BPPD Kabupaten Ciamis which as a whole is packaged in video content and contains the promotion of superior tourism village products in Kabupaten Ciamis. This activity is the result of the collaboration between BPPD Kabupaten Ciamis and the Dinas Pariwisata Kabupaten Ciamis to increase tourist visits and the quality of tourism in Kabupaten Ciamis. The uniqueness of the Kegiatan Desaku Wisataku is that as an event, Desaku Wisataku directly involves the community. In addition, the Kegiatan Desaku Wisataku are also a new innovation in terms of tourism promotion during the Covid-19 pandemic. This study aims to examine the marketing communication activities of the BPPD Kabupaten Ciamis through Desaku Wisataku using the concept of event management, promotion mix and event approaches as well as analyzing solutions to the obstacles contained in these activities. The research method used is qualitative with a case study. The data collection techniques used were interviews, observation and documentation. The results of this study indicate that the Kegiatan Desaku Wisataku applies the concept of event management Goldblatt which consist of research, planning, design, coordination and evaluation. There are several obstacles in Desaku Wisataku such as coordination, awareness and understanding of the community, finances, weather conditions and human resources. The solution taken was to carry out further communication and make changes to the schedule of Desaku Wisataku.
\end{abstract}

Keywords: Marketing Communication, Kegiatan Desaku Wisataku, Event.

\begin{abstract}
Abstrak. Kegiatan Desaku Wisataku merupakan program rutin tahunan BPPD Kabupaten Ciamis yang secara keseluruhan dikemas dalam konten video dan berisi tentang promosi produk unggulan desa wisata di Kabupaten Ciamis. Kegiatan tersebut merupakan hasil dari kolaborasi BPPD Kabupaten Ciamis dan Dinas Pariwisata Kabupaten Ciamis untuk meningkatkan kunjungan wisatawan dan kualitas pariwisata Kabupaten Ciamis. Keunikan yang dimiliki oleh Kegiatan Desaku Wisataku yaitu bahwa sebagai event, Desaku Wisataku melibatkan pihak masyarakat secara langsung. Selain itu, Kegiatan Desaku Wisataku juga merupakan inovasi baru dalam hal promosi pariwisata saat pandemi Covid-19. Penelitian ini bertujuan untuk mengkaji mengenai aktivitas marketing komunikasi Badan Promosi Pariwisata Daerah (BPPD) Kabupaten Ciamis melalui Kegiatan Desaku menggunakan konsep manajemen event, bauran promosi dan pendekatan event serta menganalisis solusi dari hambatan yang terdapat pada kegiatan tersebut. Metode penelitian yang digunakan yaitu kualitatif dengan pendekatan studi kasus. Teknik pengumpulan data yang digunakan yaitu wawancara, observasi dan dokumentasi. Hasil dari penelitian ini yaitu bahwa Kegiatan Desaku Wisataku mengaplikasikan konsep manajemen event Goldblatt yang terdiri dari research, perencanaan, desain, koordinasi dan evaluasi. Kegiatan Desaku Wisataku mengalami beberapa hambatan yaitu seperti koordinasi, kesadaran dan pemahaman masyarakat, finansial, keadaan cuaca dan SDM. Solusi yang dilakukan yaitu melakukan komunikasi lanjut dan melakukan perubahan jadwal Kegiatan Desaku Wisataku.
\end{abstract}

Kata Kunci: Komunikasi Pemasaran, Kegiatan Desaku Wisataku, Event. 


\section{A. Pendahuluan}

Badan Promosi Pariwisata Daerah (BPPD) Kabupaten Ciamis merupakan sebuah badan yang memiliki tugas dan fungsi untuk melakukan promosi kepariwisataan di Kabupaten Ciamis. BPPD Kabupaten Ciamis berkolaborasi dengan Dinas Pariwisata Kabupaten Ciamis untuk meningkatkan kunjungan wisatawan dan kualitas pariwisata Kabupaten Ciamis. Sejauh ini, BPPD Kabupaten Ciamis telah melakukan berbagai upaya untuk meningkatkan kunjungan wisatawan di Kabupaten Ciamis tersebut. Mulai dari melalui periklanan, media online, word to mouth, personal selling hingga event/kegiatan.

Salah satu kegiatan yang dilaksanakan dan telah menjadi program rutin tahunan BPPD Kabupaten Ciamis yaitu Desaku Wisataku. Desaku Wisataku menyajikan keunikan dan kekhasan pedesaan yang ada di Ciamis. Desaku Wisataku juga menunjukkan bahwa desa-desa di Kabupaten Ciamis layak menjadi desa yang siap untuk dikunjungi wisatawan. Desaku Wisataku dikemas melalui konten video yang berisi tentang promosi produk unggulan di desa wisata tersebut dengan indikator agrowisata, budaya kuliner dan ekonomi kreatif.

Kegiatan Desaku Wisataku sebagai marketing komunikasi dari BPPD Kabupaten Ciamis ini telah melalui berbagai promosi untuk sampai kepada masyarakat Kabupaten Ciamis. Keunikan yang dimiliki oleh Kegiatan Desaku Wisataku yaitu bahwa sebagai event, Desaku Wisataku melibatkan pihak masyarakat secara langsung. Masyarakat di daerah sekitar tidak hanya berperan sebagai pihak yang menghadiri dan menonton event tersebut, melainkan menjadi bagian dalam pembuatan konten Kegiatan Desaku Wisataku. Dengan dilaksanakannya kegiatan Desaku Wisataku, maka masyarakat Ciamis dapat menjadi pelaku promosi pariwisata dan bukan hanya sebagai pihak yang disuguhi terkait kepariwisataan. Masyarakat diberi peran untuk bebas menyampaikan aspirasi yang kreatif dan inovatif melalui konten video di desa masing-masing.

Selain itu, Kegiatan Desaku Wisataku juga merupakan inovasi baru dalam hal promosi pariwisata saat pandemi Covid-19. Sebagai upaya peningkatan kunjungan wisata ke Kabupaten Ciamis dan mengingat pemberlakuan protokol kesehatan Covid-19, Kegiatan Desaku Wisataku menjadi solusi dari hal tersebut. Kegiatan Desaku Wisataku disajikan dalam bentuk konten video sehingga pelaku pelaksanaan dari event pun dibatasi.

BPPD Kabupaten Ciamis bermaksud menunjukkan keberagaman potensi pariwisata di Kabupaten Ciamis dan keunikan tersendiri yang dimilikinya. Maka, BPPD terus membuka peluang untuk mendorong dan mengembangkan pariwisata secara terus menerus sehingga mempunyai daya saing tinggi. Kabupaten Ciamis merupakan daerah yang memiliki berbagai objek pariwisata. Pariwisata tersebut seperti wisata alam, sejarah, edukasi, religi, minat khusus dan buatan. Anugerah itulah yang menjadikan Kabupaten Ciamis menjadi daerah yang bisa dikunjungi oleh pelancong domestik maupun mancanegara (Badan Promosi Pariwisata Daerah Kabupaten Ciamis, 2020).

Penulis akan melakukan penelitian dengan judul Aktivitas Promosi Badan Promosi Pariwisata Daerah (BPPD) Kabupaten Ciamis. Penulis hendak meneliti proses-proses dan pelaksanaan promosi melalui event yaitu Kegiatan Desaku Wisataku tersebut dengan menggunakan konsep komunikasi pemasaran dan konsep manajemen event yang mengarah pada kesesuaian tujuan dilaksanakannya sebuah event.

Berdasarkan latar belakang di atas, maka perumusan masalah dalam penelitian ini sebagai berikut: "Bagaimana aktivitas promosi Badan Promosi Pariwisata Daerah (BPPD) Kabupaten Ciamis pada Kegiatan Desaku Wisataku?" Selanjutnya, tujuan dalam penelitian ini diuraikan dalam pokok-pokok sebagai berikut:

1. Untuk mengkaji pelaksanaan Kegiatan Desaku Wisataku sebagai upaya promosi Badan Promosi Pariwisata Daerah (BPPD) Kabupaten Ciamis.

2. Untuk menganalisis solusi terhadap hambatan yang terjadi pada Kegiatan Desaku Wisataku.

3. Mengapa Badan Promosi Pariwisata Daerah (BPPD) Kabupaten Ciamis menggunakan Kegiatan Desaku Wisataku sebagai salah satu upaya promosi pariwisata? 


\section{B. Metodologi Penelitian}

Penelitian studi kasus merupakan penelitian dengan menggunakan berbagai sumber data yang nantinya akan digunakan untuk meneliti, menguraikan, dan menjelaskan secara komprehensif berbagai aspek baik individu, kelompok, program, organisasi ataupun peristiwa secara sistematis dan terstruktur (Kriyantono, 2006: 65). Herdiansyah (2019: 76) menjelaskan bahwa salah satu ciri khas dari pendekatan studi kasus adalah adanya "sistem yang terbatas". Sistem yang terbatas ini merupakan batasan terhadap waktu dan tempat serta hal kasus yang diangkat. Ciri lain yang dimiliki oleh pendekatan studi kasus yaitu adanya keunikan dari kasus yang diangkat.

Berdasarkan ciri dari studi kasus ini, memiliki kesesuaian dengan kasus yang akan diteliti yaitu Kegiatan Desaku Wisataku. Kegiatan ini memiliki batasan waktu dan tempat serta memfokuskan pada pelaksanaan event sebagai upaya promosi pariwisata. Keunikan pada penelitian ini yaitu bahwa Kegiatan Desaku Wisataku merupakan event yang tidak hanya dilaksanakan untuk diberikan kepada khalayak sasarannya, melainkan khalayaknya pun dapat ikut serta berkontribusi di dalamnya.

Dalam Wahyuningsih (2019: 17) dijelaskan desain studi kasus tunggal memberikan kemungkinan untuk melakukan eksplorasi secara mendalam dan spesifik mengenai suatu kejadian (atau beberapa peristiwa) dari sebuah fenomena. Penggunaan desain studi kasus tunggal dapat dilakukan ketika kasus yang diteliti mewakili beberapa poin yaitu (1) kasus kritis untuk menguji teori, (2) kasus yang tidak biasa atau unik, (3) kasus umum yang dapat menambah pemahaman pada peristiwa tertentu, (4) kasus yang sebelumnya tidak dapat diakses, (5) kasus longitudinal (Prihatsanti dkk, 2018: 130).

Komunikasi pemasaran adalah bagian dari komunikasi yang memfokuskan tujuannya untuk memengaruhi khalayak sesuai dengan kehendaknya. Komunikasi pemasaran/marketing communication menjadi salah satu sarana yang dapat digunakan oleh sebuah perusahaan dalam memberikan informasi, melakukan persuasi, dan menjadi pengingat bagi konsumennya baik secara langsung ataupun tidak mengenai satu produk atau jasa yang sedang dijual (Firmansyah, 2020: 2).

Promosi adalah setiap upaya marketing yang fungsinya untuk memberikan informasi atau meyakinkan para konsumen yang potensial mengenai kegunaan suatu produk atau jasa dengan tujuan untuk mendorong konsumen baik melanjutkan atau memulai pembelian pada harga tertentu (Putra dan Maryani, 2017: 239).

Event merupakan sebuah kegiatan yang diselenggarakan dalam rangka merayakan hal-hal penting bagi manusia baik oleh perorangan ataupun perkelompok yang terikat secara adat, budaya, tradisi dan agama, diselenggarakan demi terwujudnya suatu tujuan dengan melibatkan berbagai pihak lain serta berlangsung pada waktu tertentu (Wirata, 2018: 5). Pemanfaatan event yang digunakan sebagai alat promosi perusahaan seringkali dinilai lebih efektif daripada pengalokasian uang untuk beriklan di media massa. Dibandingkan dengan alat komunikasi pemasaran yang lain, event melibatkan targeted audience merupakan alat publikasi yang lebih ampuh. Selain itu, event juga dapat mendorong penyebaran aktivias word of mouth tentang brand karena di dalamnya melibatkan emosi audience (Suhendra dan Wardhani, 2014: 139 140).

Dalam Hartono, dkk (2016: 164) dijelaskan bahwa manajemen event adalah suatu kegiatan profesional dengan upaya mengumpulkan dan mempertemukan orang-orang atau khalayaknya untuk suatu tujuan seperti perayaan, pemasaran, pendidikan dan reuni, serta bertanggung jawab dalam melakukan riset, membuat desain dan perencanaan, melaksanakan koordinasi dengan berbagai pihak serta evaluasi untuk merealisasikan sebuah kegiatan. Pelaksanaan sebuah event tentunya membutuhkan konsep manajemen yang baik untuk mewujudkan harapan dan tujuan yang telah ditentukan bersama sejak awal. Menurut Goldblatt (dalam Pudjiastuti, 2010: 39-41), terdapat lima tahap untuk dapat menghasilkan sebuah event yang efektif dan efisien yaitu riset, desain, perencanaan, koordinasi dan evaluasi. Penyelenggara event perlu memperhatikan beberapa pendekatan yang mendukung terwujudnya tujuan dari sebuah event. Menurut Leonard H. Hoyle (dalam Sukoco, 2014: 751) pendekatan tersebut yaitu entertainment, excitement, dan enterprise. 


\section{Hasil Penelitian dan Pembahasan}

\section{Pelaksanaan Kegiatan Desaku Wisataku}

Berdasarkan hasil analisis data terbangunnya kesadaran orang tua bahwa anak terdapat pengimplementasian dari teori dan konsep manajemen event Goldblatt, yaitu riset, desain, perencanaan, koordinasi, dan evaluasi. Dalam tahap riset, Kegiatan Desaku Wisataku diamati berdasarkan implementasi $5 \mathrm{~W}+1 \mathrm{H}$ (what, where, when, who, why dan how).

Melalui riset yang dilakukan secara mendalam penyelenggara dapat melihat trend yang sedang berkembang, mengembangkan sistem penyediaan layanan baru, dan memecahkan masalah kecil sebelum menjadi masalah besar (Ibrahim, 2015: 18-19). Pada tahap riset, pihak BPPD Kabupaten Ciamis melakukan penentuan terhadap tujuan yaitu untuk promosi, memberi informasi dan edukasi yang mencakup peningkatan pemahaman masyarakat. Khalayak dari Kegiatan Desaku Wisataku ditargetkan secara umum kepada masyarakat Kabupaten Ciamis ataupun Indonesia tanpa batasan apapun. Waktu dan lokasi pelaksanaan event direncanakan berdasarkan jumlah desa yang sudah ditentukan berdasarkan kesesuaian SK Desa Wisata dan potensi pariwisata di desa. Pihak yang terlibat merupakan pihak yang kredibel dan memiliki integritas tinggi yaitu Dinas Pariwisata Kabupaten Ciamis, BPPD Kabupaten Ciamis sebagai tim pelaksana dan masyarakat di desa sebagai pendukung. Perihal anggaran biaya Kegiatan Desaku Wisataku berasal dari Dinas Pariwisata dan dibuat berdasarkan keadaan di lapangan.

Pada tahap desain, pihak BPPD Kabupaten Ciamis melakukan penentuan desain dari Kegiatan Desaku Wisataku. Dalam tahap desain sebuah special event terdapat beberapa unsur yang harus dirancang dengan sebaik mungkin. Karena dengan rancangan desain yang baik akan memberikan kontribusi besar pada kesuksesan sebuah acara (Pudjiastuti, 2010: 27). BPPD Kabupaten Ciamis memilih nama "Desaku Wisataku" karena sesuai dengan tujuan pelaksanaan kegiatan yaitu untuk mempromosikan dan mengembangkan desa wisata di Kabuapten Ciamis.

BPPD Kabupaten Ciamis melakukan penentuan atas unsur-unsur seperti pemilihan bentuk konten yang dibuat dalam bentuk video dengan alasan dapat memuat pesan yang maksimal untuk kemudian diunggah ke Youtube. Pesan yang dimuat berupa pesan informatif, edukatif, hiburan dan persuasif. Sehingga khalayak dapat merasakan berbagai manfaat dari Kegiatan Desaku Wisataku. Selain itu, pesan juga disampaikan baik secara verbal ataupun non verbal melalui video. Unsur artistic lain dari konten Kegiatan Desaku Wisataku yaitu dari pengambilan gambar di alam, pemilhan host serta proses editing.

Pada tahap perencanaan, hal-hal yang direncanakan yaitu meliputi timeline perencanaan pembuatan dan publikasi konten serta media yang digunakan dalam publikasi. Timeline Kegiatan Desaku Wisataku dimulai dari bulan Mei hingga bulan Juni. Selama dua bulan tersebut, proses pembuatan, editing hingga penayangan konten Desaku Wisataku sudah dijadwalkan. Pada intinya, Kegiatan Desaku Wisataku dilaksanakan secara berkala dengan sistem syuting - editing - penayangan. Adapun proses tersebut dilaksanakan berdasarkan urutan desa-desa yang telah ditetapkan sesuai dengan timeline. Setelah melalui tahap editing, konten video Desaku Wisataku diitayangkan/dipublikasikan melalui beberapa media seperti Youtube, Instagram, Facebook dan Website. Media yang digunakan tentunya memiliki karakteristik yang berbeda satu sama lain. Pemilihan media-media tersebut sudah direncanakan sesuai dengan tujuan dan fungsi dalam menyampaikan pesan serta menjangkau khalayaknya.

Pada tahap koordinasi, pihak BPPD Kabupaten Ciamis melaksanakannya dengan beberapa pihak seperti pihak Dinas Pariwisata dan pihak masyarakat di desa-desa. Koordinasi tersebut dilakukan dengan tujuan dapat menyatukan perspektif terkait tujuan dan visi misi Kegiatan Desaku Wisataku. Koordinasi dilaksanakan melalui beberapa cara seperti rapat, diskusi, perorangan, sosialisasi ataupun melalui media. Ada beberapa tantangan yangsering kali harus dihadapi tim dalam berkoordinasi. Menurut Goldblatt tantangan tersebut adalah factor komunikasi, kepentingan pribadi, komitmen, kepercayaan, dan kolaborasi (Pudjiastuti 
2010: 97).

Tahap terakhir, yaitu tahap evaluasi dalam Zubair dan Syahidah (2017: 48) dijelaskan bahwa tahap ini merupakan tahap penentuan dari hasil serangkaian kegiatan yang sudah dilaksanakan, termasuk penilaian terhadap efektivitas persiapan program, implementasi perencanaan, sampai tercapai atau tidaknya tujuan kegiatan. Pihak BPPD Kabupaten Ciamis melakukan evaluasi terkait ketepatan pelaksanaan Kegiatan Desaku Wisataku dengan timeline dan hamabtan apa saja yang terjadi.

Pelaksanaan Kegiatan Desaku Wisataku berhasil terlaksana sesuai dengan timeline yang direncakan sejak awal meskipun terdapat beberapa perubahan pada timeline tersebut. Hal ini menunjukkan bahwa Kegiatan Desaku telah mendapat perhatian serta dukungan dari pihakpihak yang terlibat. Selain itu, meski timbul beberapa hambatan secara internal ataupun eksternal, hal tersebut dapat diatasi dengan baik. Berbagai permasalahan yang timbul tidak menghambat Kegiatan Desaku Wisataku secara berlebihan ataupun berkelanjutan.

\section{Solusi dari Hambatan pada Kegiatan Desaku Wisataku}

Pelaksanaan Kegiatan Desaku Wisataku tentunya mengalami beberapa hambatan. Hambatan tersebut yaitu meliputi

1. Koordinasi

Hambatan koordinasi yaitu terjadi dalam internal tim pelaksana Kegiatan Desaku Wisataku. Hambatan koordinasi pada Kegiatan Desaku Wisataku terjadi secara internal, pada saat pemberian tugas dan jobdesk masing-masing. Solusi yang dilakukan yaitu melakukan koordinasi ulang baik dengan melaksanakan meeting/rapat, komunikasi langsung dari atasan ke bawahan ataupun diskusi bersama. Sedangkan hambatan koordinasi dengan eksternal yaitu seperti terjadinya kerumunan masyarakat yang tidak sesuai dengan rencana. Mengingat bahwa sekarang ini sedang dilakukan pembatasan kerumunan untuk memutus rantai penyebaran Covid-19 maka dilakukan koordinasi lebih lanjut dengan pihak kepolisian, puskesmas dan perangkat desa setempat untuk ikut serta membantu menertibkan masyarakat.

2. Pemahaman dan kesadaran masyarakat

Masyarakat belum sepenuhnya memiliki pemahaman dan kesadaran akan pentingnya promosi pariwisata untuk pengembangan desa wisata ataupun poteni pariwisata yang ada. Dengan adanya Kegiatan Desaku Wisataku sebagai upaya promosi, maka dapat ikut serta membangun ekonomi masyarakat di desa tersebut. Solusi yang dilakukan yaitu tim pelaksana menjelaskan maksud dan tujuan Kegiatan Desaku Wisataku kepada masyarakat serta berkoordinasi dengan pihak tertentu untuk ikut serta menertibkan dan membantu terjalannya Kegiatan Desaku Wisataku.

\section{Finansial}

Masyarakat menganggap bahwa dengan adanya Kegiatan Desaku Wisataku, akan diberi sejumlah uang. Solusi yang dilakukan yaitu memberikan komunikasi dengan menjelaskan bahwa Kegiatan Desaku Wisataku murni dilakukan sebagai upaya promosi pariwisata dari Dinas Pariwisata Kabupaten Ciamis bersama BPPD Kabupaten Ciamis. Pihak tim pelaksana juga memberikan insentif kepada masyarakat untuk membantu pengembangan desa wisata.

4. Keadaan cuaca

Cuaca ini sangat berpengaruh karena Kegiatan Desaku Wisataku dilakukan secara outdoor dengan mengambil gambar-gambar alam ataupun sajian kesenian di luar ruangan. Maka dari itu, untuk menyelesaikan hambatan karena keadaan cuaca, tim pelaksana BPPD Kabupaten Ciamis melakukan perubahan jadwal dengan menggantikan jadwal pembuatan konten Kegiatan Desaku Wisataku dari satu desa, ke desa lain terlebih dahulu. Meskipun terdapat perubahan jadwal pada timeline awal, tapi tidak mengubah timeline secara keseluruhan karena hanya beberapa desa saja yang jadwalnya diubah. Selain itu, perubahan ini juga membantu agar Kegiatan Desaku Wisataku dapat terus berjalan sesuai dengan sesuai dengan deadline yang ditentukan.

5. SDM

SDM tim pelaksana atau SDM yang ada di BPPD Kabupaten Ciamis masih belum 
tersertifikasi secara resmi. Tetapi, SDM tersebut sudah memiliki kemampuan yang kompeten dalam penyelesaian berbagai kegiatan termasuk Kegiatan Desaku Wisataku. Solusi dalam hambatan SDM ini yaitu menjadikannya sebagai peluang, untuk menunjukkan bahwa BP2D Kabupaten Ciamis mampu membuat berbagai konten yang kredibel dengan SDM yang dimiliki. Selain itu, untuk ke depannya juga ada rencana bahwa SDM BP2D Kabupaten Ciamis akan mengikuti beberapa sertifikasi untuk mendapatkan sertifikat resmi yang diakui oleh lembaga-lembaga sertifikasi nasional.

\section{Pemilihan Event sebagai Media Promosi}

BPPD Kabupaten Ciamis event sebagai media promosi yaitu karena melalui event dapat meningkatkan wawasan, brand awareness dan juga sekaligus promosi. Dalam Wulandari dkk (2017: 44) dijelaskan bahwa salah satu cara yang ampuh dalam mempromosikan keunikan dan keunggulan daerah adalah dengan mengadakan kegiatan atau event marketing. Event marketing mempunyai kekuatan yang luar biasa untuk menciptakan brand awareness kepada konsumen sehingga dalam dirinya tumbuh fanatisme terhadap produk tertentu. Maka dari itu, BPPD Kabupaten Ciamis berhasil menggunakan salah satu upaya promosi untuk memberikan informasi dan edukasi dengan kata lain brand awareness masyarakat di Kabupaten Ciamis mengenai pariwisata khususnya destinasi wisata dan ekonomi kreatif. Kegiatan Desaku Wisataku menyuguhkan berbagai informasi dan hiburan bagi masyarakat serta memberikan kenangan bagi pihak yang terlibat secara langsung atapun tidak.

Selain menerapkan konsep manajemen event, BPPD Kabupaten Ciamis juga menerapkan pendekatan-pendekatan event. Menurut Hoyle Leonard, H (2006), terdapat tiga pendekatan yang harus diperhatikan dalam menyelenggarakan sebuah event, yang dikenal dengan "3E" yaitu entertainment, enterprise dan excitement. Ditinjau berdasarkan aspek hiburan, kenangan dan kesiapan kru menanggung resiko maka Badan Promosi Parwisata Daerah Kabupaten Ciamis dalam pelaksanaan event Desaku Wsiataku telah memerhatikan hal tersebut. Hiburan pada Desaku Wisataku dapat ditinjau dari isi konten pada video, kenangan yang diberikan pun berupa kesenangan dan rasa bangga yang dirasakan oleh tim serta masyarakat.

Alasan BPPD Kabupaten Ciamis memilih event Kegiatan Desaku Wisata sebagai media promosi karena event sebagai aktivitas promosi merupakan upaya yang paling efektif dalam menjangkau khalayak. Maksud dari efektif disin yaitu memberikan pemahaman dan wawasan secara langsung dan jelas kepada masyarakat khususnya di desa-desa di Kabupaten Ciamis.

\section{Kesimpulan}

Berdasarkan pembahasan dalam penelitian ini, peneliti menyimpulkan beberapa hasil penelitian sebagai berikut:

1. Berlandaskan pada tinjauan pustaka yaitu konsep manajemen event Goldblatt yang terdiri dari riset, desain, perencanaan, koordinasi dan evaluasi. Pada Kegiatan Desaku Wisataku, Badan Promosi Pariwisata Daerah (BPPD) Kabupaten Ciamis mengimplementasikannnya dengan maksimal. Pada tahap riset, BPPD Kabupaten Ciamis melakukan perancangan mengenai tujuan event yaitu sebagai mengangkat potensi pariwisata dan mempromosikannya, meningkatkan wawasan dan kesadaran (brand awareness) masyarakat mengenai pariwisata, memberi stimulan dan bantuan kepada pelaku pariwisata, ikut serta berupaya dalam mengurangi dampak Covid-19 dengan menyajikan konten-konten yang bisa diakses di media sosial serta membantu meningkatkan pergerakan ekonomi di desa-desa di Kabupaten Ciamis.

Selain itu, pada tahap riset juga dilakukan perancangan terkait khalayak event, waktu dan lokasi event serta pihak-pihak yang terlibat. Pada tahap desain, BPPD Kabupaten Ciamis menentukan nama kegiatan, format/bentuk konten Kegiatan Desaku Wisataku yang akhirnya digunakanlah bentuk audiovisual, konsep isi pesan berupa informatif, edukatif dan hiburan serta unsur-unsur artistik yang terdapat pada konten Kegiatan Desaku Wisataku. Pada tahap perencanaan, dilakukan pembuatan konsep terhadap rencana publikasi dan media yang digunakan. Pada tahap koordinasi, dilakukan 
berbagai koordinasi berupa rapat, surat, diskusi, perorangan, sosialisasi ataupun melalui media dengan beberapa pihak yang terlibat. Dan pada tahap evaluasi dilakukan pembahasan mengenai ketepatan timeline dan hambatan yang terjadi.

Dengan mengaplikasikan konsep manajemen event, pelaksanaan Kegiatan Desaku Wisataku dapat lebih jelas dan terstruktur secara sistematis. Berbagai hal yang diperlukan telah direncanakan sebelum pelaksanaan kegiatan berlangsung. Konsep manajemen event juga membantu memudahkan pelaksanaan Kegiatan Desaku Wisataku saat mengalammi hal-hal lain di luar dugaan.

2. Berlandaskan pada analisis data hambatan yang terjadi pada Kegiatan Desaku Wisataku yaitu meliputi koordinasi, kesadaran dan pemahaman masyarakat, finansial, keadaan cuaca dan SDM. Solusi yang dilakukan yaitu melakukan berbagai komunikasi dengan pihak terkait untuk memberikan penjelasan terkait pelaksanaan Kegiatan Desaku Wisataku. Selain itu dilakukan juga perubahan jadwal Kegiatan Desaku Wisataku dengan memerhatikan keadaan cuaca di beberapa daerah serta kesesuaian timeline dan deadline. Hambatan yang terjadi tidak menghentikan pelaksanaan Kegiatan Desaku Wisataku karena dilakukan pemilihan solusi yang berdasar pada berbagai hal. Selain itu, telah dilakukan juga identifikasi dalam mengatasi kemungkinan hambatan saaat proses perencanaan kegiatan.

3. Kegiatan Desaku Wisataku dipilih sebagai media promosi oleh Badan Promosi Parwisata Daerah (BPPD) Kabupaten Ciamis dengan tujuan sebagai media informasi, edukasi (brand awareness), hiburan dan promosi. Pemiliha pelaksasnaan Kegiatan Desaku Wisataku juga memperhatikan pendekatan-pendekatan event. Pendekatanpendekatan event tersebut meliputi entertainment, enterprise dan excitement. Dengan diaplikasikannya pendekatan-pendekatan event pada Kegiatan Desaku Wisataku, maka Kegiatan Desaku Wisataku dapat terlaksana dengan baik dan sesuai dengan kaidah dilaksanakannya sebuah event.

\section{Acknowledge}

Penulis mengucapkan terima kasih kepada Badan Promosi Pariwisata Daerah Kabupaten Ciamis dan Dinas Pariwisata Kabupaten Ciamis yang telah mendukung dan membantu dalam memberikan data maupun informasi untuk tujuan penelitian ini.

\section{Daftar Pustaka}

[1] Badan Promosi Pariwisata Daerah Kabupaten Ciamis. 2020. Kegiatan Desaku Wisataku. Ciamis: Dinas Pariwisata Kabupaten Ciamis.

[2] Hatrono, N. A., Dida, S., \& Hafiar, H. 2016. "Pelaksanaan Kegiatan Special Event Jakarta Goes Pink Oleh Lovepink Indonesia" dalam Jurnal Komunikasi, Volume X, Nomor 02, September 2016 (hlm. 161-172).

[3] Herdiansyah, H. 2019. Metode Penelitian Kualitatif untuk Ilmu-Ilmu Sosial. Jakarta: Salemba Humanika.

[4] Ibrahim, Agus. 2016. Manajemen Event Maulid Adat Bayandi Lombok Utara Tahun 2015. Skripsi. Yogyakarta: Universitas Muhamadiyah Yogyakarta.

[5] Kriyantono, R. 2006. Teknik Praktis Riset Komunikasi. Jakarta: Kencana Prenadamedia Group.

[6] Prihatsanti, U., Suryanto., Hendriani, W. 2018. "Menggunakan Studi Kasus sebagai Metode Ilmiah dalam Psikologi" dalam Jurnal Buletin Psikologi. Volume 26, Nomor 2 (hlm. 126 - 136).

[7] Pujiyati, S., Ridho, A.F., \& Permathasari, A. D. 2017. Statistik Objek Daya Tarik Wisata 2017. Jakarta: OBadan Pusat Statistik.

[8] Putra, M. P., dan Anne Maryani. 2017. Kesenian Gagak Layang sebagai Media Promosi Pariwisata Kota Bandung. Prosiding Manajemen Komunikasi. Bandung. Hal. 238-244).

[9] Suhendra, F. I., dan Ike Juanita. 2014. Manajemen Event Pameran Pernikahan 
Tradisional Lintas Warna. Prosiding Penelitian Sivitas Akademika Unisba (Sosial dan Humaniora). Bandung. Hal. 139 - 144.

[10] Sukoco, M. H. 2014. "Pengaruh Pemasaran Event Terhadap Citra Merek Minuman Isotonik Mizonedi Surabaya" dalam Jurnal Ilmu Manejemen. Volume 2, Nomor 3, Juli 2014 (hlm. 748-758).

[11] Wahyuningsih, Sri. 2019. Metode Penelitian Studi Kasus. Madura: UTM Press.

[12] Wirata, I. N. 2018. Pengelolaan Event. Depok: PT. RajaGrafindo Persada.

[13] Zubair, Feliza., dan Shahidah, Dara Anjani. 2017. Kajian Menejemen Special Event Goldblatt Dalam Road Show Santri Sehat Oleh Pt. Bio Farma dalam jurnal Acta Diurna Vol. 13 No.1 hal. 36-51. 